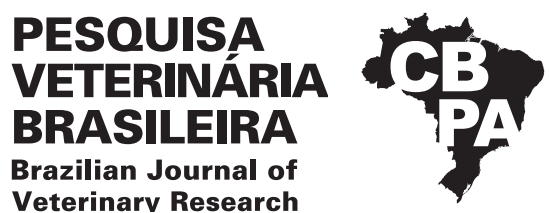

\title{
Craniometric geographical variation in Hylaeamys megacephalus populations ${ }^{1}$
}

\author{
Paola S. Mata ${ }^{2 *}$ (1), Matheus S.L. Ribeiro², Michel B. Faria² and Fabiano C. Lima²
}

\begin{abstract}
Mata P.S., Ribeiro M.S.L., Faria M.B. \& Lima F.C. 2020. Craniometric geographical variation in Hylaeamys megacephalus populations. Pesquisa Veterinária Brasileira 40(9):726732. Programa de Biociência Animal, Universidade Federal de Jataí, Cidade Universitária, BR-364 Km 195, Prédio da Pós-Graduação, Jataí, G0 75801-615, Brazil. E-mail: paoladamata@hotmail.com

Hylaeamys megacephalus (G. Fisher, 1814) presents great genetic diversity and wide geographical distribution, and occurs in both the Amazon and Cerrado biomes. Because of its generalist aspect, this species tolerates different eating habits and habitats. It occurs in flooded and dry areas and is predominantly terrestrial, which allows greater gene flow between populations even over long distances. Studies that seek a better understanding of morphological variations resulting from differences imposed by the environment throughout this species' distribution are still lacking. This study aimed to analyze the differences between H. megacephalus populations based on craniometry, investigating whether the environment has an influence on morphology. We analyzed a total of 142 specimens from three scientific mammal collections: National Museum, "Universidade Federal do Rio de Janeiro" (MNUFRJ); "Laboratório de Biologia e Parasitologia de Mamíferos Reservatórios Silvestres", "Instituto Oswaldo Cruz", "Fundação Oswaldo Cruz"(LBCE-Fiocruz); and "Laboratório de Biodiversidade", "Universidade Federal de Goiás", "Regional Jataí" (LZE-UFG), and took 20 craniometric measurements. Craniometry was explored using unweighted pair group method with arithmetic mean (UPGMA), canonical variate analysis, and principal component analysis (PCA). The results led us to conclude that there are three craniometric groups of $H$. megacephalus with a tendency to differentiate as a result of geographical influences.
\end{abstract}

INDEX TERMS: Craniometry, geographic variation, Hylaeamys megacephalus, anatomy, morphological characters, skull, occurrence, rodent.

RESUMO.- [Variação geográfica craniométrica em populações de Hylaeamys megacephalus.] Com grande diversidade genética e distribuição geográfica, Hylaeamys megacephalus (G. Fisher, 1814) ocorre tanto na Amazônia quanto no Cerrado. Visto seu aspecto generalista, esta espécie tolera diversos hábitos alimentares e habitats, ocorrendo em áreas inundadas ou não, sendo predominantemente terrestre, permitindo maior fluxo de genes entre as populações, mesmo em longas distâncias. Apresenta ampla distribuição, e carece de estudos que busquem um melhor entendimento sobre as variações morfológicas resultantes das diferenças impostas pelo meio ao longo de sua distribuição. 0 estudo teve como objetivo, analisar as diferenças entre as populações de $H$. megacephalus, com base na craniometria investigando se o

\footnotetext{
${ }^{1}$ Received on April 22, 2020.

Accepted for publication on June 22, 2020.

${ }^{2}$ Programa de Biociência Animal, Universidade Federal de Jataí, Cidade Universitária, BR-364 Km 195, Prédio da Pós-Graduação, Jataí, GO 75801615, Brazil. *Corresponding author: paoladamata@hotmail.com
}

ambiente interfere na morfologia. Analisamos um total de 142 espécimes oriundos de coleções científicas de mamíferos, do Museu Nacional, Universidade Federal do Rio de Janeiro (MNUFRJ), Laboratório de Biologia e Parasitologia de Mamíferos Reservatórios Silvestres, Instituto Oswaldo Cruz, Fundação Oswaldo Cruz (LBCE-Fiocruz) e Laboratório de Biodiversidade, Universidade Federal de Goiás, Regional Jataí, nos quais foram tomadas 20 medidas craniométricas. A craniometria foi explorada nas análises estatísticas de agrupamento de pares não ponderados com médias aritméticas (UPGMA), variação canônica e análise dos Componentes Principais (PCA). Os resultados encontrados nos levaram a concluir a existência de três grupos craniométricos da espécie de H. megacephalus com tendência a se diferenciarem, por influências geográficas.

TERMOS DE INDEXAÇÃO: Variação geográfica, craniometria, Hylaeamys megacephalus, anatomia, caracteres morfológicos, crânio, ocorrência, roedor. 


\section{INTRODUCTION}

The evolutionary success of rodents may be attributed to their small body size, high-rate and short-cycle reproduction, and wide range of dental characteristics (Rodrigues \& Naehrer 2012). This specification is surprising, and it can be found in almost all non-marine habitats. The adaptive diversity of these animals is remarkable in ecology, as they occur in most ecosystems on the planet (Hautier et al. 2011, Arregoitia et al. 2017).

Hylaeamys megacephalus (G. Fisher, 1814) (Azara's broadheaded oryzomys or large headed rice rat) presents great genetic diversity and wide geographical distribution, and occurs in both the Amazon and Cerrado biomes, forming three clades in three different regions: one in the Cerrado and two in the Amazon (north and south of the Amazonas River). Genes of the clade belonging to the south of the Amazonas River are closer to those of the clade that inhabits the Cerrado, suggesting an allopatric divergence in which historical and ecological factors have an influence on the distribution and diversification of species (Miranda et al. 2007, Machado et al. 2019).

Because of its generalist aspect, $H$. megacephalus tolerates several eating habits and habitats. It occurs in flooded and dry areas and is predominantly terrestrial, which allows greater gene flow between populations even over long distances. This rodent has a wide distribution, and studies that seek a better understanding of morphological variations resulting from differences imposed by the environments are still lacking (Emmons \& Feer 1997, Bonvicino et al. 2008, Percequillo et al. 2008, Rocha et al. 2011, Paglia et al. 2012, Rocha et al. 2014, Patton et al. 2015).

Morphological variation in these animals can be explained by different ecological and/or evolutionary mechanisms, such as intraspecific and sexual selection. Size and shape are critical biological attributes of organisms, resulting from the interaction between genes and environment. Usually, a large fraction of the variability of morphometric data is related to the size of individuals, which can result in changes in the associated shape (Kardong 2014).

This study aimed to analyze the differences between $H$. megacephalus populations based on craniometry, investigating whether the environment has an influence on morphology.

\section{MATERIALS AND METHODS}

Samples. Cranial morphology was assessed in 142 specimens from three mammal scientific collections: 63 from the National Museum, "Universidade Federal do Rio de Janeiro" (MN-UFRJ), 49 from the "Laboratório de Biologia e Parasitologia de Mamíferos Reservatórios Silvestres", "Instituto Oswaldo Cruz", "Fundação Oswaldo Cruz" (LBCE-Fiocruz), and 30 from the "Laboratório de Biodiversidade", "Universidade Federal de Goiás", "Regional Jataí" (LZE-UFG) (Table 1). They are distributed over 27 Brazilian municipalities: seven in the Amazon and 20 in the Cerrado biomes. For statistical analysis, locations with fewer than five specimens were grouped into the closest geographical region (Table 2 and Fig.1).

Quantitative analysis. The samples were analyzed in January 2018 at the MN-UFRJ and LBCE-Fiocruz, and in July 2018 at the LZE-UFG. Adult individuals of both sexes were analyzed. Age was classified according to the third molar eruption criterion (Fig.2). Cranial dimensions were measured following an adaptation from Voss (1988) and Manduca (2008) using a digital precision (0.01 mm) caliper. Twenty measurements were taken (Table 3 and Fig.3-5).
Statistical analysis. Cluster analysis was performed using the unweighted pair group method with arithmetic mean (UPGMA) (Sneath \& Sokal 1973). The cut-off point was established using the k-means clustering analysis to favor interpretation of score distribution patterns in the multivariate space. Subsequently, we performed canonical variate analysis, for discriminatory morphometric trends, and principal component analysis (PCA), based on the covariance matrix of the logarithmically transformed data used to determine the main independent trends in craniometric variation. The 20 craniometric variables were analyzed using the $\mathrm{R}$ software and descriptive statistics (mean and standard deviation). Small population samples ( $<5$ specimens) were grouped into larger samples from the closest geographical location (Fig.1).

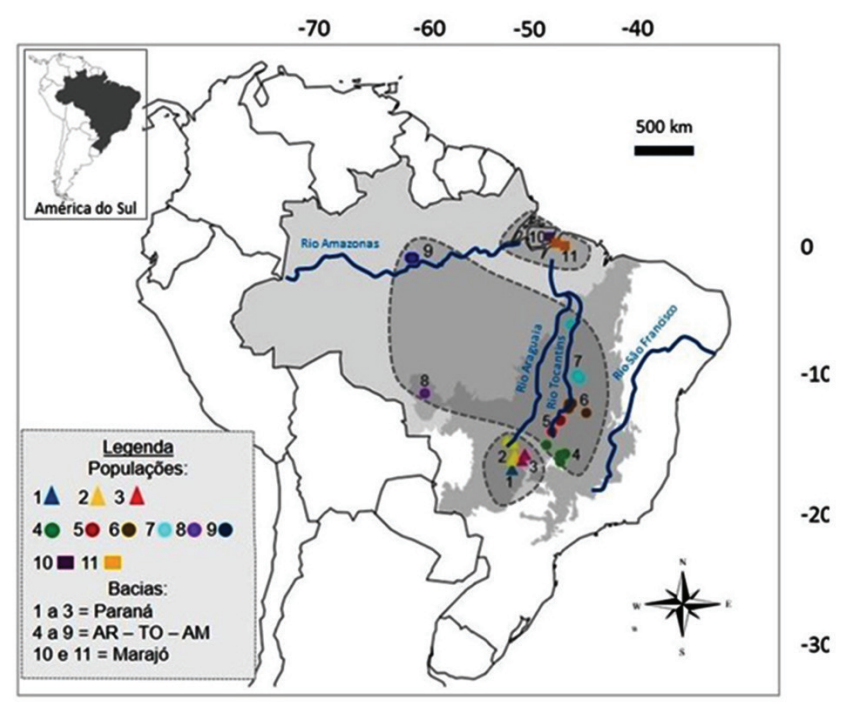

Fig.1. Distribution map of the collected Hylaeamys megacephalus samples, where each color and number indicates the geographically grouped populations and the symbols show the groups in the UPGMA analysis.

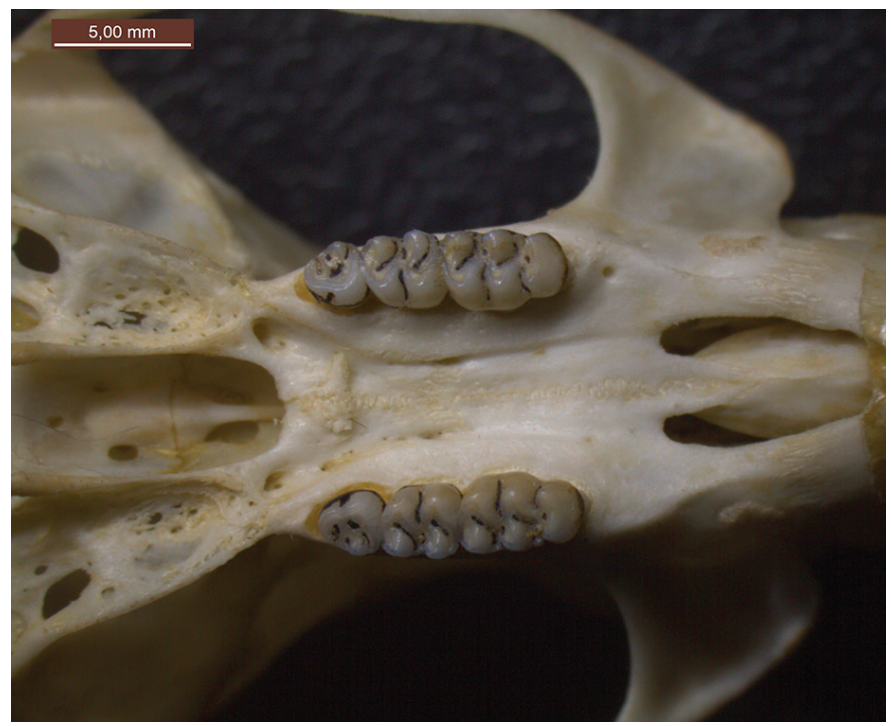

Fig.2. Microphotograph of the molar teeth showing the third molar (3M) eruption in Hylaeamys megacephalus, specimen 079 LZE, ventral view. 
Table 1. Origin of the Hylaeamys megacephalus specimens analyzed

\begin{tabular}{|c|c|c|c|c|c|c|}
\hline Number & Institution & $\begin{array}{l}\text { Morphoclimatic } \\
\text { domain }\end{array}$ & Latitude & Longitude & Municipality & State* \\
\hline $6986,6987,8566,9456,7003,7471,7491,8511,9442$ & LBCE & Cerrado & $18^{\circ} 57^{\prime} 55^{\prime \prime} \mathrm{S}$ & $51^{\circ} 55^{\prime} 35^{\prime \prime} \mathrm{W}$ & Aporé & GO \\
\hline $8754,8751,8752,8755$ & LBCE & Cerrado & $17^{\circ} 37^{\prime} 59^{\prime \prime} \mathrm{S}$ & $47^{\circ} 46^{\prime} 42^{\prime \prime} \mathrm{W}$ & $\begin{array}{l}\text { Campo Alegre } \\
\text { de Goiás }\end{array}$ & GO \\
\hline 8718 & LBCE & Cerrado & $16^{\circ} 57^{\prime} 44^{\prime \prime} \mathrm{S}$ & 49 $13^{\prime} 41^{\prime \prime} \mathrm{W}$ & Hidrolândia & GO \\
\hline 8768 & LBCE & Cerrado & $17^{\circ} 43^{\prime} 19^{\prime \prime} \mathrm{S}$ & $48^{\circ} 09^{\prime} 35^{\prime \prime} \mathrm{W}$ & Ipameri & GO \\
\hline $\begin{array}{c}13523,13522,13524,13542,13519,13027,13024 \\
13023,13028,13031\end{array}$ & LBCE & Cerrado & $11^{\circ} 49^{\prime} 26^{\prime \prime} \mathrm{S}$ & $46^{\circ} 37^{\prime} 42^{\prime \prime} \mathrm{W}$ & Novo Jardim & TO \\
\hline $\begin{array}{c}13004,13005,13025,13059,13029,13030,13084 \\
13437,13526,13543,13467,13070,13065\end{array}$ & LBCE & Cerrado & $11^{\circ} 37^{\prime} 40^{\prime \prime} \mathrm{S}$ & $46^{\circ} 49^{\prime} 14^{\prime \prime} \mathrm{W}$ & Dianópolis & TO \\
\hline 18587 & LBCE & Cerrado & $18^{\circ} 15^{\prime} 47^{\prime \prime} \mathrm{S}$ & $48^{\circ} 09^{\prime} 04^{\prime \prime} \mathrm{W}$ & Cumari & GO \\
\hline $12194,12152,12158,12172$ & LBCE & Cerrado & $12^{\circ} 59^{\prime} 22^{\prime \prime} \mathrm{S}$ & $58^{\circ} 45^{\prime} 51^{\prime \prime} \mathrm{W}$ & Sapezal & MT \\
\hline $\begin{array}{c}54,78,80,82,83,87,89,90,92,96,129,144,154,156, \text { TX } \\
03,79,141\end{array}$ & LZE & Cerrado & $17^{\circ}-52$ ' $53^{\prime \prime} \mathrm{S}$ & $51^{\circ} 42^{\prime} 52^{\prime \prime} \mathrm{W}$ & Jataí & GO \\
\hline 165 & LZE & Cerrado & $18^{\circ} 17^{\prime} 56^{\prime \prime} \mathrm{S}$ & $51^{\circ} 08^{\prime} 43^{\prime \prime} \mathrm{W}$ & $\begin{array}{l}\text { Aparecida do } \\
\text { Rio Doce }\end{array}$ & GO \\
\hline 167 & LZE & Cerrado & $16^{\circ} 57^{\prime} 24^{\prime \prime} \mathrm{S}$ & $51^{\mathrm{o}} 48^{\prime} 37^{\prime \prime} \mathrm{W}$ & Caiapônia & GO \\
\hline 177 & LZE & Cerrado & $16^{\circ} 43^{\prime} 13^{\prime \prime} \mathrm{S}$ & $52^{\circ} 19^{\prime} 10^{\prime \prime} \mathrm{W}$ & Doverlândia & GO \\
\hline $221,245,251,255,212,213,217,219,256$ & LZE & Cerrado & $17^{\circ} 47^{\prime} 53^{\prime \prime} \mathrm{S}$ & $50^{\circ} 55^{\prime} 41^{\prime \prime} \mathrm{W}$ & Rio Verde & $\mathrm{GO}$ \\
\hline 69 & LZE & Cerrado & $18^{\circ} 57^{\prime} 55^{\prime \prime} \mathrm{S}$ & $51^{\circ} 55^{\prime} 35^{\prime \prime} \mathrm{W}$ & Aporé & GO \\
\hline $\begin{array}{c}\text { 20880, 20882, 20883, 20886, 20888, 20889, 20890, } \\
\text { 20892, 20877, 20878, 20695, 20893, 20895, 20897, } \\
\begin{array}{c}2098,20899,20900,20901,20904,20911,20913 \\
69002,75119\end{array}\end{array}$ & $\begin{array}{c}\text { Museu } \\
\text { Nacional -UFRJ }\end{array}$ & Amazônia & $03^{\circ} 06^{\prime} 07^{\prime \prime} \mathrm{S}$ & $60^{\circ} 01^{\prime} 30^{\prime \prime} \mathrm{W}$ & Manaus & AM \\
\hline 10289,10288 & LBCE & Amazônia & $01^{\circ} 00^{\prime} 41^{\prime \prime} \mathrm{S}$ & $48^{\circ} 57^{\prime} 48^{\prime \prime} \mathrm{W}$ & $\begin{array}{l}\text { Cachoeira do } \\
\text { Arari }\end{array}$ & $\mathrm{PA}$ \\
\hline 69185 & $\begin{array}{l}\text { Museu } \\
\text { Nacional -UFRJ }\end{array}$ & Amazônia & $00^{\circ} 58^{\prime} 29^{\prime \prime} \mathrm{S}$ & $62^{\circ} 55^{\prime} 27^{\prime \prime} \mathrm{W}$ & Barcelos & AM \\
\hline 84037 & $\begin{array}{l}\text { Museu } \\
\text { Nacional -UFRJ }\end{array}$ & Amazônia & $01^{\circ} 40^{\prime} 27^{\prime \prime} \mathrm{S}$ & $47^{\circ} 46^{\prime} 16^{\prime \prime} \mathrm{W}$ & Capim & PA \\
\hline $84036,84035,84034,84033,84031,84030,84032$ & $\begin{array}{l}\text { Museu } \\
\text { Nacional -UFRJ }\end{array}$ & Amazônia & $01^{\circ} 27^{\prime} 21^{\prime \prime S}$ & $48^{\circ} 30^{\prime} 16^{\prime \prime} \mathrm{W}$ & Belém & $\mathrm{PA}$ \\
\hline $46867,46861,46863$ & $\begin{array}{l}\text { Museu } \\
\text { Nacional -UFRJ }\end{array}$ & Cerrado & $14^{\circ} 07^{\prime} 57^{\prime \prime} \mathrm{S}$ & $47^{\circ} 30^{\prime} 36^{\prime \prime} \mathrm{W}$ & Alto Paraíso & GO \\
\hline 46864,46870 & $\begin{array}{l}\text { Museu } \\
\text { Nacional -UFRJ }\end{array}$ & Cerrado & $13^{\circ} 47^{\prime} 51^{\prime \prime} \mathrm{S}$ & $47^{\circ} 27^{\prime} 30^{\prime \prime} \mathrm{W}$ & Cavalcante & GO \\
\hline \multirow{5}{*}{$\begin{array}{c}43013,43014,43009,43015,43011 \\
43018,43019,43020,43021,46860 \\
81664,81665 \\
81666,81669 \\
81670,81671 \\
81672,81673 \\
81674,81675 \\
81676\end{array}$} & $\begin{array}{l}\text { Museu } \\
\text { Nacional -UFRJ }\end{array}$ & Cerrado & $13^{\circ} 46^{\prime} 35^{\prime \prime} \mathrm{S}$ & $47^{\circ} 15^{\prime} 53^{\prime \prime} \mathrm{W}$ & $\begin{array}{l}\text { Teresina de } \\
\text { Goiás }\end{array}$ & GO \\
\hline & $\begin{array}{c}\text { Museu } \\
\text { Nacional -UFRJ }\end{array}$ & Cerrado & $15^{\circ} 03^{\prime} 22^{\prime \prime} \mathrm{S}$ & $48^{\circ} 09^{\prime} 41^{\prime \prime} \mathrm{W}$ & $\begin{array}{l}\text { Mimoso de } \\
\text { Goiás }\end{array}$ & GO \\
\hline & $\begin{array}{c}\text { Museu } \\
\text { Nacional -UFRJ }\end{array}$ & Cerrado & $15^{\circ} 55^{\prime} 25^{\prime \prime} \mathrm{S}$ & $48^{\circ} 48^{\prime} 31^{\prime \prime} \mathrm{W}$ & $\begin{array}{c}\text { Corumbá de } \\
\text { Goiás }\end{array}$ & GO \\
\hline & LBCE & Cerrado & $14^{\circ} 29^{\prime} 16^{\prime \prime} \mathrm{S}$ & $46^{\circ} 06^{\prime} 47^{\prime \prime} \mathrm{W}$ & Mambaí & GO \\
\hline & LBCE & Cerrado & $18^{\circ} 18^{\prime} 22^{\prime \prime} \mathrm{S}$ & 51 57' 44" W & Serranópolis & GO \\
\hline
\end{tabular}

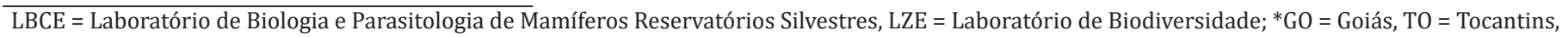
MT = Mato Grosso, AM = Amazonas, $\mathrm{PA}=$ Pará.

Table 2. Number of samples, place of origin, and number of specimens analyzed

\begin{tabular}{|c|c|}
\hline Samples & Specimen location and quantity \\
\hline 1 & Aporé - GO (10) \\
\hline 2 & Caiapônia - G0 (01), Doverlânida - GO (01), Jataí - GO (17), Serranopólis - G0 (03) \\
\hline 3 & Aparecida do Rio Doce - GO (01), Rio Verde - GO (09) \\
\hline 4 & Campo Alegre de Goiás - GO (04), Cumari - GO (01), Hidrolândia - GO (01), Ipameri - G0 (01) \\
\hline 5 & Corumbá de Goiás - GO (01), Mimoso de Goiás - GO (11) \\
\hline 6 & Alto Paraíso - G0 (03), Cavalcante - G0 (02), Goiatins - TO (01), Mambaí - G0 (01), Teresina de Goiás - G0 (14) \\
\hline 7 & Dianopólis - TO (13), Novo Jardim - TO (10) \\
\hline 8 & Sapezal - MT (04) \\
\hline 9 & Manaus - AM (21), Santa Isabel - AM (01) \\
\hline 10 & Barcelos - AM (01), Cachoeira do Arari - AM (02) \\
\hline 11 & Bélem - PA (07), Capim - PA (01) \\
\hline
\end{tabular}




\section{RESULTS}

A total of 11 populations were observed and arranged in three cranial groups listed by hydrographic basins: Marajó Island, Paraná, and Araguaia-Tocantins/Amazonas River (Fig.1). Statistical analysis (UPGMA) showed that the populations from the Paraná and Araguaia-Tocantins/Amazonas River basins are more similar to each other compared with the those from the Marajó Island (Fig.6).

As in the UPGMA analysis, canonical variate analysis also showed discriminatory morphometric trends with formation

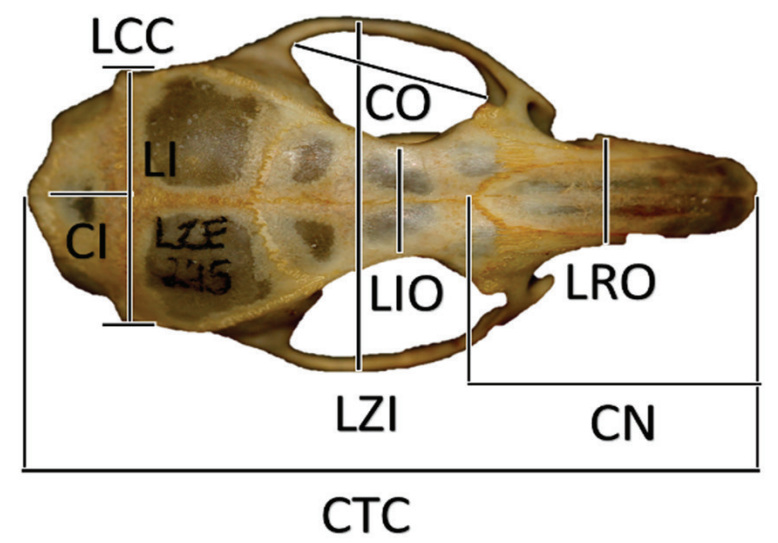

Fig.3. Dorsal view of the skull of Hylaeamys megacephalus, specimen 080 LZE. Total skull length (CTC), nasal length (CN), rostral width (LRO), interorbital width (LIO), zygomatic arch width (LZI), orbital length (CO), interparietal width (LI), skull width (LCC), interparietal length (CI).

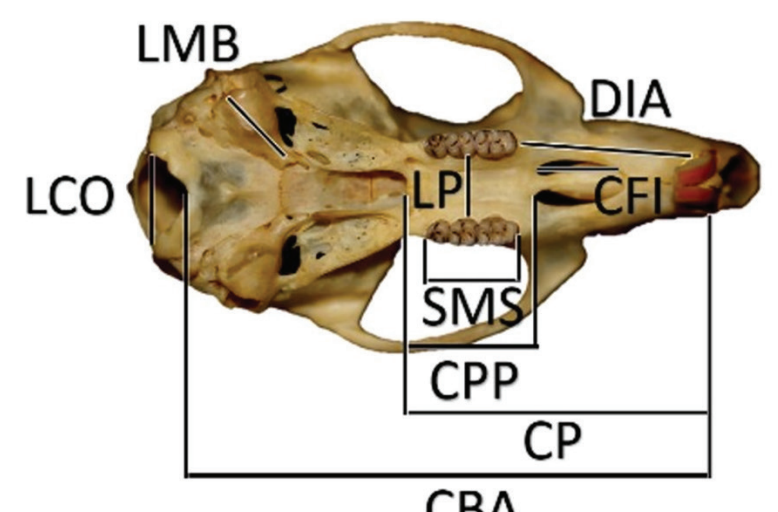

CBA

Fig.4. Ventral view of the skull of Hylaeamys megacephalus, specimen 080 LZE. Cranial base length (CBA), palatal length (CP), palatal bridge length (CPP), upper molar teeth series (SMS), palatal width (LP), incisive foramen length (CFI), diastema (DIA), maximum bulla width (LMB), distance between the occipital condyles (LCO).

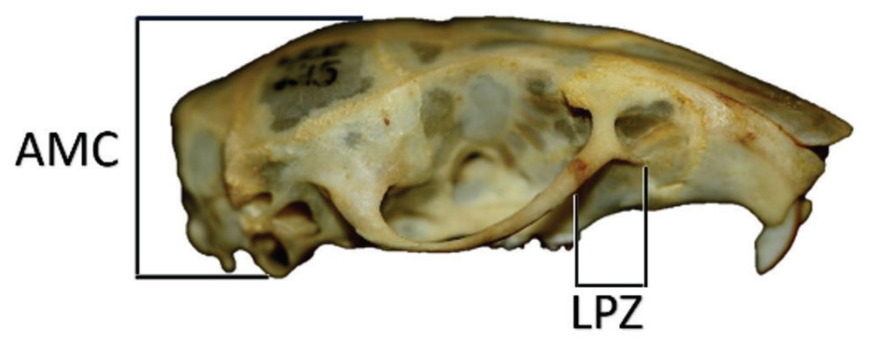

Fig.5. Lateral view of the skull of Hylaeamys megacephalus, specimen 080 LZE. Zygomatic plate width (LPZ), maximum skull height (AMC).

Table 3. Cranial characters represented by their acronyms, meaning and description

\begin{tabular}{|c|c|c|}
\hline Acronyms & Meaning & Description \\
\hline AMC & Maximum skull height & Distance between the basisphenoid-basioccipital suture and the frontoparietal suture. \\
\hline CBA & Cranial base length & Distance between the posterior border of the incisor alveolus and the anterior border of the foramen magnum. \\
\hline CFI & $\begin{array}{l}\text { Incisive foramen } \\
\text { length }\end{array}$ & Distance between the anterior border and the posterior border of the incisor foramen. \\
\hline $\mathrm{CI}$ & Interparietal length & Anteroposterior distance of the median axis of the interparietal. \\
\hline CN & Nasal length & Distance between the anterior border of the nasal and the nasofrontal suture. \\
\hline $\mathrm{CP}$ & Palatal length & Distance between the posterior border of the incisor alveolus and the border of the palate. \\
\hline СРP & Palatal bridge length & Distance between the posterior border of the incisor foramen and the border of the palate. \\
\hline СТC & Total skull length & Maximum distance measured between the anterior border of the nasal and the posterior border of the occiput. \\
\hline DIA & Diastema & Distance between the posterior alveoli of the incisors and the anterior alveoli of the first molar. \\
\hline LCC & Skull width & Width between the anterior regions of the squamous suture and the occiput. \\
\hline LMB & Maximum bulla width & $\begin{array}{l}\text { Maximum distance between the junction of the basisphenoid and basioccipital sutures and the outer border of the } \\
\text { bulla. }\end{array}$ \\
\hline LP & Palatal width & Width between the molar series measured between the first and second molars. \\
\hline LPZ & Zygomatic plate width & Distance measured at the base of the zygomatic plate from the anterior to the posterior limit. \\
\hline LRO & Rostral width & Rostrum width measured at the height of the infraorbital foramen. \\
\hline LZI & Zygomatic arch width & Greater distance between the lateral borders of the zygomatic arch. \\
\hline SMS & $\begin{array}{l}\text { Upper molar teeth } \\
\text { series }\end{array}$ & $\begin{array}{l}\text { Distance between the border of the anterior alveolus of the first molar and the border of the posterior alveolus of } \\
\text { the third molar. }\end{array}$ \\
\hline
\end{tabular}


of three population groups: Araguaia-Tocantins/Amazonas River, Paraná, and Marajó Island. However, in the discriminatory analysis, these three groups overlapped regarding craniometry, with a tendency to segregate (Fig.7).

In PCA, the first component, axis 1 (PC1), synthesizes the dorsal metrics (CTC, IOL, CN, LZI, LCC, and CO) and corresponds to $27.7 \%$ of the variation, whereas the second component, axis 2 (PC2), synthesizes the ventral metrics (CFI, SMS, CP, LCO, and CBA) and represents $8.5 \%$ of the variation (Fig.8). The most significant morphometric differences were found in the ventral metrics, making them the main component responsible for distinction between the samples.

The structured morphological groups point to a strong relationship between the populations from the Amazonas River and Tocantins-Araguaia basins, and a less intense relationship between the Araguaia-Tocantins/Amazonas River and Paraná basins. In turn, the Araguaia-Tocantins/Amazonas River and Paraná basins alone show more significant craniometric differentiation when compared with each other. The isolated populations from the Marajó Island also proved to be different from the others. However, we emphasize that, because the data referring to the Marajó Island present a low number of analyzed specimens, they may have induced separation of the analyses, causing a deviation.

As for the craniometric characters evaluated for Hylaeamys megacephalus, the mean varied between a minimum of 2.62 (LP) and a maximum of 31.10 (CTC) and the standard deviation ranged from 0.29 (IOL) to 2.52 (LZI), as shown in Table 4.

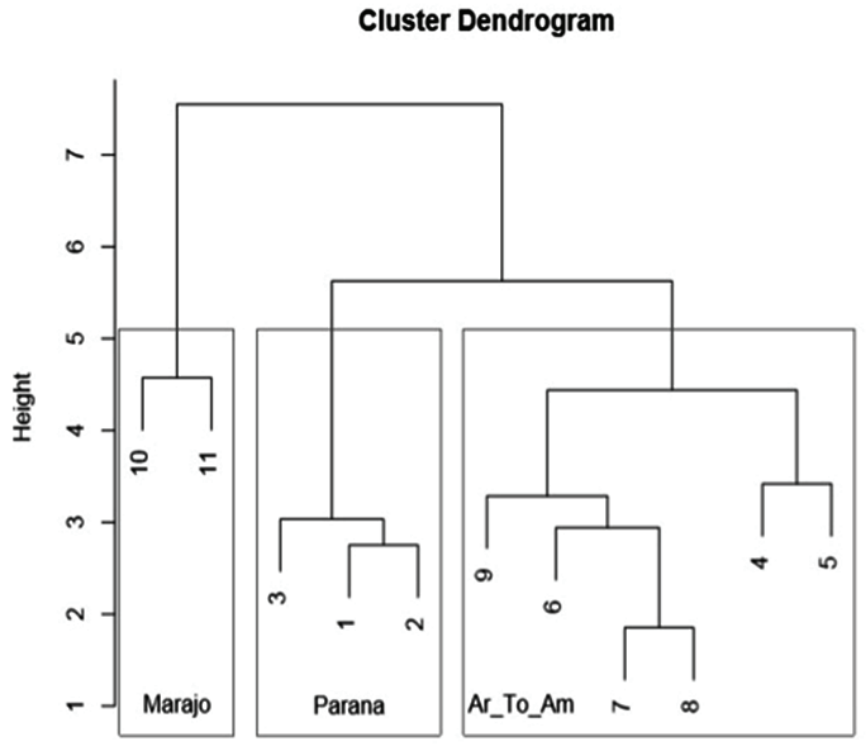

Fig.6. Cluster dendrogram of the Hylaeamys megacephalus populations according to craniometry by hydrographic basin.

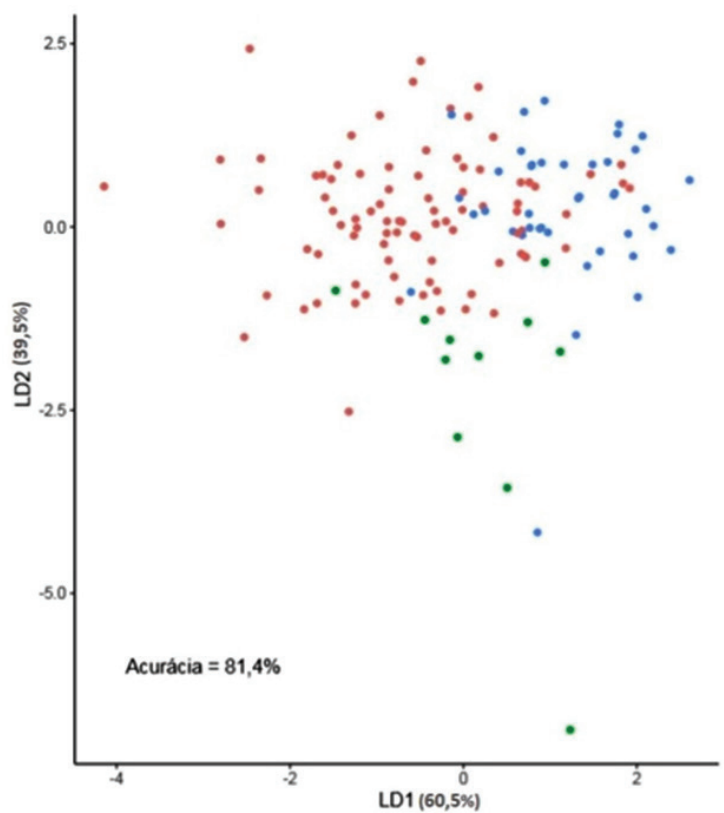

Fig.7. Canonical variate analysis discriminating the three population groups by hydrographic basin.

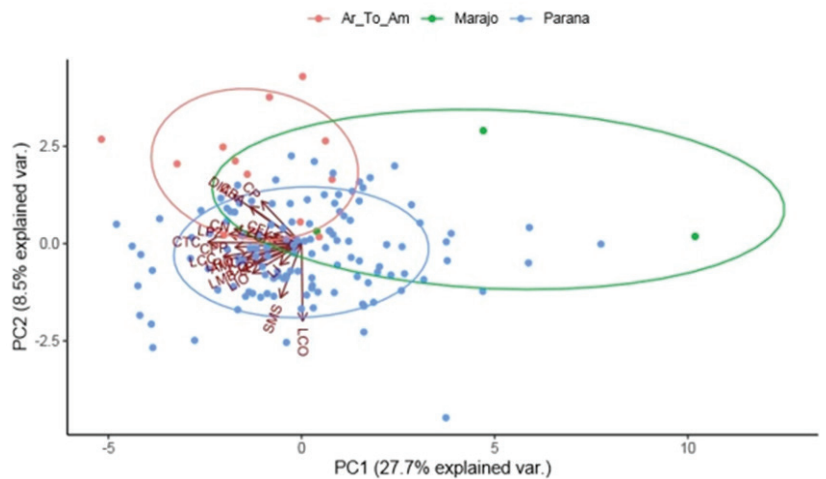

Fig.8. Principal component analysis (PCA) between the Hylaeamys megacephalus populations showing the craniometric characters. Principal components: axis 1 (PC1) synthesizes the dorsal metrics, representing $27.7 \%$ of the variation; axis 2 (PC2) synthesizes the ventral metrics, corresponding to $8.5 \%$ of the variation.

Table 4. Mean and standard deviation of the 20 craniometric characters of the Hylaeamys megacephalus samples

\begin{tabular}{ccc}
\hline Craniometric characters & Mean & Standard deviation \\
\hline CTC & 31.10 & 1.34 \\
LIO & 5.18 & 0.29 \\
CN & 12.83 & 0.86 \\
CFI & 4.23 & 0.41 \\
DIA & 8.16 & 0.66 \\
LZI & 15.21 & 2.52 \\
LCC & 11.83 & 0.45 \\
LRO & 6.00 & 0.50 \\
SMS & 4.68 & 0.34 \\
LPZ & 3.64 & 0.32 \\
CP & 13.68 & 1.41 \\
CPP & 6.95 & 0.45 \\
LCO & 3.46 & 0.54 \\
CBA & 24.52 & 2.02 \\
CI & 4.04 & 0.54 \\
LI & 9.80 & 0.80 \\
LP & 2.62 & 0.29 \\
CO & 9.25 & 0.53 \\
AMC & 9.13 & 0.42 \\
LMB & 5.23 & 0.49
\end{tabular}


The Araguaia-Tocantins and Amazonas River basins presented higher CP, DIA and CBA values than the Paraná basin, with these characters related to internal morphology. In contrast, the Paraná basin showed higher SMS values than the Araguaia-Tocantins/Amazonas River basin, with differences also related to internal morphological variables. The Marajó Island basin population groups differ from the other two groups with respect to external variables (CPP, CTC, LPZ, LMB, LIO, AMC, and LRO), with lower values for these variables observed in the first.

\section{DISCUSSION}

According to Marroig (2007), a simple increase in skull size can lead animals to consume larger and harder food items or become more resistant to explore new environments and niches. Our results suggested that the morphological characteristic is associated with the environment where the species lives. For this reason, we correlated the craniometric results to the hydrographic basins.

Most of the variables involved in these morphometric differences are associated with the general structure of the skull. The SMS and CP measures, for example, directly contribute to the adaptation of the oral cavity structure, allowing changes in food acquisition habits. Differences in shape can mean functional differences performed by the same parts, revealing different responses when subjected to the same selective pressure (Schmidt-Nielsen 1984, Van Valkenburgh 1994).

Measurement variations should be interpreted so that the components that represent structural measures can and, usually, play an essential role in functional adaptation. Over time, such adaptations have enabled individuals to develop specializations. In this case, the skull shape is highly valuable for these interpretations, because the differences in length and width, such as in the palate, oral cavity or molar teeth series, directly represent the possibility of restructuring the diet.

Analysis of the craniometric similarity between the Hylaeamys megacephalus populations from the AraguaiaTocantins and Amazonas River basins, population 9, located north of the Amazonas River, is craniometrically similar to the other populations of the Cerrado biome (Fig.1 and 6). Thus, our results compared the genetic data reported by Miranda et al. (2007) and Machado et al. (2019), who stated that genes of the clade belonging to the south of the Amazonas River are closer to those of the clade that inhabits the Cerrado, suggesting an allopatric divergence.

This difference between morphological and genetic data can be explained by the use of markers, since the changes observed in morphological characteristics occur through a relatively slower process compared with those in genetic characteristics. The contrast between these data can be justified by geographical influences, despite the strong geographical barrier exerted by the Amazonas River, which affects gene flow. This isolation directly affects two speciation components: the development and establishment of divergence between different forms of discontinuity (Mayr 1970).

Thus, differences between species are influenced by geographical variations and, whether morphological, physiological or ecological, they are potentially isolating mechanisms that reinforce the distinction between two populations (Pearson 2007).

\section{CONCLUSION}

Morphological analysis shows the existence of three craniometric groups of Hylaeamys megacephalus with a tendency to differentiate as a result of geographical influences.

Acknowledgments.- The authors are grateful to the "Museu Nacional", Universidade Federal do Rio de Janeiro (MN-UFRJ), "Laboratório de Biologia e Parasitologia de Mamíferos Reservatórios Silvestres”, Instituto Oswaldo Cruz, Fundação Oswaldo Cruz (LBCE-Fiocruz), and "Laboratório de Biodiversidade", “Universidade Federal de Goiás", “Regional Jataí” (LZEUFG) for providing the samples used in this study, and to the "Coordenação de Aperfeiçoamento de Pessoal de Nível Superior" (CAPES), Brazil, for the grant provided to the first author.

Conflict of interest statement.- The authors have no competing interests.

\section{REFERENCES}

Arregoitia L.D.V., Fisher D.O. \& Schweizer M. 2017. Morphology captures diet and locomotor types in rodents. Royal Soc. Open Sci. 4(1):160957. <https://dx.doi.org/10.1098/rsos.160957><PMid:28280593>

Bonvicino C.R., Oliveira J.A. \& D’andrea P. 2008. Guia dos roedores do Brasil, com chaves para gêneros baseadas em caracteres externos. Centro PanAmericano de Febre Aftosa, Organização Pan-Americana da Saúde (OPAS/ OMS), Rio de Janeiro.

Emmons L.H. \& Feer F. 1997. Neotropical rainflorest mammals: a field guide. $2^{\underline{a}}$ ed. The university of Chicago Press, Chicago.

Hautier L., Lebrun R., Saksiri S., Michaux J., Vianey-liaud M. \& Marivaux L. 2011. Hystricognathy $v s$ sciurognathy in the rodent jaw: a new morphometric assessment of hystricognathy applied to the living fossil Laonastes (Diatomyidae). PLoS One 6(4):e18698. <https://dx.doi.org/10.1371/ journal.pone.0018698><PMid:21490933>

Kardong K.V. 2014. Vertebrados: anatomia comparada, função e evolução. Editora Rocca. São Paulo. 913p.

Machado A.F., Nunes M.S., Silva C.R., Dos Santos M.A., Farias I.P., Da Silva M.N.F. \& Anciães M. 2019. Integrating phylogeography and ecological niche modelling to test diversification hypotheses using a Neotropical rodent. Evol.Ecol.33:111-148.<https://dx.doi.org/10.1007/s10682-019-09968-1>

Manduca E.G. 2008. Estudo das variações morfológicas cranianas e citogenéticas em Akodon Cursor (Rodentia: Sigmodontinae) de remanescentes de Mata Atlântica no estado de Minas Gerais. Master's Thesis, Universidade Federal de Viçosa, Viçosa, MG.

Marroig G. 2007. When size makes a difference: allometry, life-history and morphological evolution of capuchins (Cebus) and squirrels (Saimiri) monkeys (Cebinae, Platyrrhini). BMC Evolutionary Biology 7:20. <https://dx.doi.org/10.1186/1471-2148-7-20><PMid:17300728>

Mayr E. 1970. Populations, species, and evolution: an abridgment of animal species and evolution. Harvard University Press. 472p.

Miranda G.B., Andrades-Miranda J., Oliveira L.F.B., Langguth A. \& Mattevi M.S. 2007. Geographic patterns of genetic variation and conservation consequences in three South American rodents. Biochem. Genet. 45(11/12):839-856. <https://dx.doi.org/10.1007/s10528-007-9122-x> <PMid:17939030>

Paglia A.P., Fonseca G.A.B., Rylands A.B., Herrmann G., Aguiar L.M.S., Chiarello A.G., Leite Y.L.R., Costa L.P., Siciliano S., Kierulff M.C.M., Mendes S.L., Tavares V.C., Mittermeier R.A. \& Patton J.L. 2012. Lista Anotada dos Mamíferos do Brasil [Annotated Checklist of Brazilian Mammals]. 2nd ed. Occasional Papers in Conservation Biology No.6, Conservation International, Arlington, VA. 76p.

Patton J.L., Pardiñas U.F.J. \& D’elía G. 2015. Mammals of South America Rodents. Vol.2. University of Chicago Press, Chicago.

Pearson R.G. 2007. Species' distribution modeling for conservation educators and practitioners. Lessons in Conservation, 3:54-89. 
Percequillo A.R., Hingst-Zaher E. \& Bonvicino C.R. 2008. Systematic review of genus Cerradomys Weksler, Percequillo and Voss, 2006 (Rodentia: Cricetidae: Sigmodontinae: Oryzomyini), with description of two new species from eastern Brazil. American Museum Novitates (3622):1-46. <https://dx.doi.org/10.1206/495.1>

Rocha L.F.N., Silva I.G. \& Luz C. 2011. Activity of some hypocrealean fungi collected in a Cerrado ecosystem against Rhodnius spp. (Hemiptera: Reduviidae) under laboratory conditions. Acta Trop. 118(1):63-66. <https://dx.doi.org/10.1016/j.actatropica.2011.01.004><PMid:21251907>

Rocha R.G., Ferreira E., Fonseca C., Justino J., Leite Y.L.R. \& Costa L.P. 2014. Seasonal flooding regime and ecological traits influence genetic structure of two small rodents. Ecol. Evol. 4(24):4598-4608. <https://dx.doi. org/10.1002/ece3.1336>
Rodrigues I. \& Naehrer K. 2012. Prevalence of mycotoxins in feedstuffs and feed surveyed worldwide in 2009 and 2010. Phytopathol. Mediterranea 51(1):175-192.<https://dx.doi.org/10.14601/Phytopathol_Mediterr-9693>

Schmidt-Nielsen K. 1984. Scaling: why is animal size so important. Cambridge University Press. 241p.

Sneath P.H.A. \& Sokal R.R. 1973. Numerical Taxonomy: the principles and practice of numerical classification. W. H. Freeman, San Francisco, CA. 588p.

Van Valkenburgh B. 1994. Ecomorphological analysis of fossil vertebrates and their paleocommunities, p.140-166. In: Wainwright P.C. \& Reilly M.S. (Eds), Ecological Morphology: integrative organismal biology. University of Chicago Press, Chicago.

Voss R.S. 1988. Systematics and ecology of ichthyomyine rodents (Muroidea): patterns of morphological evolution in a small adaptive radiation. Bull. Am. Museum Nat. Hist. 188:259-493. 